\title{
PRÓBA ROZWIAZZANIA KWESTII ŻYDOWSKIEJ PRZEZ LUDWIKA ZAMENHOFA
}

$\mathrm{L}$ udwik Zamenhof (1859-1914) żył w Warszawie w okresie największych antypolskich posunięć caratu, ale był to również czas największej reakcji w samej Rosji, który następuje po zabójstwie cara Aleksandra II (1818-1881). Mimo silnej unifikacji ustrojowej z Rosją, Królestwo Polskie wciąż utrzymywało jakąś odrębność, a dzięki rozwojowi wysokiej kultury, pełną tożsamość narodową i kulturową.

To, co Polacy odczuwali jako gwałt i upokorzenia rosyjskie, nie stosowało się do ludności żydowskiej, inaczej bowiem odczuwali psychospołecznie restrykcje carskie Polacy, inaczej Żydzi, oba narody celowo przez Rosjan dzielone, mające różne dzieje, interesy narodowe i odmienną aksjologię wyznaniową, obyczajową itp.

Rosjanie traktowali Polaków jako kulturowo równych sobie, a tylko wówczas, po rozbiorach, jako pokonanych, i rozstrzygali „cywilizacyjne” porachunki jeszcze sprzed ponad dwóch wieków, z pamiętnych czasów „wielkiej smuty”.

Gwałt na ludności żydowskiej i upokorzenia rosyjskie miały inny charakter, inne źródła, inne restrykcje niż na Polakach. Rosjanie nie znali wcześniej mas żydowskich, te pojawity się w Rosji dopiero po rozbiorach Polski, nagle. Chrześcijaństwo prowadziło ostre dysputy "teologiczne" z judaizmem, który wszedł w spór z filozofią grecką i kształtowat filozoficzne postawy chrześcijaństwa, w tym prawosławia. Jak wiemy z listu Filoteusza do Wasyla III (1479-1533), „Dwa Rzymy upadły, Trzeci stoi, Czwartego nie będzie, gdyż Twoje królestwo chrześcijańskie przez żadne inne nie zostanie zastąpione". W Rosji kontynuowano bizantyjski antyjudaizm, ale nie antysemityzm. Ten pojawił się, gdy dysputy teologiczne przeniosły się na zagadnienia byto-
Dr hab. Walter ŻELAZNY jest profesorem w Instytucie Kultury i Komunikowania Szkoły Wyższej Psychologii Społecznej w Warszawie. walterz@hotmail.fr 
we, zmieniające wraz z wczesnym kapitalizmem stosunek do posiadania. W pełnej krasie antysemityzm rosyjski pojawia się wraz z fałszywką wydaną jako Протоколы Сионских мудрецов z 1895 roku. Wówczas Żydzi zaczęli Rosjanom „śmierdzieć": „Żydowski organizm wydziela pot", pisał w 1896 roku protojerej Apolinary Kowalnickij, którego nie wydzielały ani plemiona murzyńskie, ani europejskie"1. Od tego czasu cywilizacyjna niższość judaizmu względem chrześcijaństwa przeniosła się na "rasową".

\section{LITWACY}

Litwacy to potomkowie Żydów Rzeczypospolitej Obojga Narodów, uboczny "produkt” rozbiorów Polski, z ziem wcielonych do imperium Romanowów. To Żydzi, którzy przybyli do Królestwa Polskiego w 1881 roku (po ponadpółwiekowej forsownej rusyfikacji) w ramach represji po zamachu na cara Aleksandra II. Był to element obcy kulturze polskiej, nieznający języka polskiego i wrogo nastawiony do polskich aspiracji niepodległościowych, z pełną indyferencją wobec polskiej niepodległości. Praktyki religijne Litwaków były znacznie mniej surowe niż Żydów polskich. Z jednej strony angażowali się oni w ruchy syjonistyczne, z drugiej w socjalistyczne i rewolucyjne, ignorując zupełnie sprawy polskie. Wykorzystywała to administracja rosyjska, nadając Litwakom rolę rusyfikatorów. Sam Zamenhof, mając 23 lata, był świadom tego, czym jest dla Litwaków Rosja i jaki jest stosunek Rosjan do Litwaków, co ironicznie zapisuje w 1882 roku:

Rosyjski naród nie kocha Was, mimo iż przybraliście już imiona Iwana czy Mikołaja. Uważa się Was za wrzód, który należy zlokalizować, a którego z radością by się pozbyto. Każdą kruszynkę chleba zjedzoną przez Was uważa się za kradzież, każdy łyk powietrza wdychany przez Was traktuje się zgrzytaniem zębami. Poproście więc o ostatnią łaskawość Tej, która zawsze będzie dla Was macochą, niech pozwoli Wam spokojnie wyjechać i wyzwolić się od Waszej obecności. Nie będziecie już więcej okradać dobrodusznego prawosławnego chłopa. Wasze dzieci nie będą już uzurpować sobie prawa do odkryć naukowych, które będą należeć do dzieci "tubylców”. Nie będziecie już ciężarem dla państwa, które wydaje na Was rok w rok setki milionów rubli. Własnymi siłami wyzwolicie Rosję z Waszej uciążliwej i zbędnej w niej obecności i nie proście od Rosjan żadnej pomocy, w sprawie tak korzystnej dla niej.

Jeśli Rosja bierze nas za tak szkodliwych dla niej, że uważa za stosowne powołać komisję do sądzenia nas, jeśli widzi w nas krowę, którą można doić i równocześnie nazywać ją pasożytem, jeśli sączy złośliwym jadem pomówień każdy wypity przez nas tyk mleka i opowiada każdemu przypadkowemu śmiertelnikowi: „oni są dopustem bożym żyjącym na nasz koszt”, jeśli naprawdę uważają nas za wrzód, a nie za pokorne sieroty, to może Rosja nie wesprze nas, ale niech przynajmniej z radością pozwoli nam samym zorganizować stąd emigrację. W ten sposób wyzwoli się od wyrzutków, a my wyzwolimy się od ciągłego poniżenia, od ciągłych oskarżeń i obelg. Odwdzięczmy się za to wzajemnością. Nie narzucajmy się sobie nawzajem!²

A jednak postępowanie Litwaków wobec Polski, Litwaków, którzy doznawali ze strony Rosji również szykan, upokorzeń, fałszywych oskarżeń, potrafiło bulwersować nawet najbardziej życzliwych im Polaków, wyzutych z jakichkolwiek uczuć nacjonalistycznych i an-

\section{$\cdots \cdots$}

K. Lewalski, Kościoły chrześcijańskie w Królestwie Polskim wobec Żydów w latach 1855-1915, Wrocław 2002, s. 121.

2 Niestety nie dotarłem do rosyjskiego oryginału tego tekstu, zamieszczonego pod tytułem что же наконеи, делать? w numerach 2, 3, 4 i 5 petersburskiego pisma "Разсвет” w 1882 roku. Ten tekst tłumaczyłem z esperanckiego przekładu dokonanego przez A. Korżenkowa, a opublikowanego w Mi estas Homo. Originalaj verkoj de d-ro L.-L. Zamenhof, Eldonejo Sezonoj, Kaliningrado 2006, s. 5-26. Wszystkie tłumaczenia w tej pracy z języków rosyjskiego, esperanto i francuskiego pochodzą od autora. 
tysemickich. Pomiędzy Żydami polskimi a Litwakami istniał antagonizm. Były to w istocie dwa oddzielne światy, które w zasadzie się nie spotykały. Tak wyglądał podział "etniczny" Żydów. Jeszcze dotkliwszy był podział "klasowy” Żydów na nieoświeconą biedotę, najczęściej chasydzką i lumpenproletariat z jednej strony, oraz na finansową magnaterię, jak rody Kronenbergów, Blochów czy Poznańskich, z drugiej.

WARSZAWA ZAMENHOFA

W Warszawie w pełni panował narodowy żywioł polski, niezniszczalny ukazami carskimi, dążący do odrodzenia suwerenności, żywioł odporny na represje po powstaniach 1830 i 1863 roku. W roku narodzin esperanta, czyli w 1887, ludność Warszawy liczyła niecałe 450 tys. mieszkańców. Na przełomie XIX i XX wieku Warszawa była miastem Polaków (ok. 60\%), Żydów (ponad 30\%) i Rosjan (zdecydowanie mniej niż 10\%), narodowo zróżnicowanym, bogatym kulturowo i rozwijającym się gospodarczo. Polacy umieli żyć W „rosyjskiej” Warszawie, co uwidocznił w Lalce Bolesław Prus, gdzie Rosjanie pojawiają się nadzwyczaj rzadko, z ironicznym sarkazmem autora, jako urzędnicy, z wyjątkiem przyjaciela Wokulskiego, Suzina. Polityka rusyfikacyjna nie była prowadzona konsekwentnie, z jednej strony zrusyfikowano bowiem polskie szkolnictwo wszystkich szczebli, z drugiej strony Teatr Wielki w Warszawie otrzymywał subwencje z Petersburga. Rozwijała się prasa, i chociaż cenzura rosyjska była wyjątkowo represyjna, to również niekonsekwentna.

Warszawa Zamenhofa, i późniejsza, była największym miastem żydowskim w Europie, w której w okresie międzywojennym funkcjonowało 440 synagog. W przeciwieństwie do Wilna czy Łodzi Warszawa nigdy nie stała sie centrum żydowskiej nauki religijnej, i wszystko wskazuje na to, że właśnie dzięki temu stała się światowym centrum kultury jidysz. Jej żydowscy mieszkańcy odegrali wyjątkową rolę w organizacji partii socjalistycznych i komunistycznych, a z drugiej strony - stronnictw syjonistycznych. Odegrali też znaczącą rolę w rozwoju literatury, teatru, kabaretu, a przede wszystkim filmu języka jidysz ${ }^{3}$. Z tego warszawskiego nurtu kultury wywodzą się tacy tytani literatury, teatru i filmu, jak: Szymon Anski (1863-1920), Icchok Lejb Perec (1852-1915), Isaac Bashevis Singer (1902-1991).

Dzielnica żydowska, a właściwie szereg sąsiadujących ze sobą wewnętrznie zróżnicowanych dzielnic, chociaż nieodcięta od reszty miasta przepisami prawnymi, nieodgrodzona murem, w świadomości mieszkańców Warszawy pozostawała odrębnym miastem. W żadnym z wielu znanych mi pamiętników polskich dotyczących dziewiętnastowiecznej Warszawy nie pojawia się dzielnica żydowska i jej mieszkańcy. Brak ten to nie najgorsza miara dystansu społecznego, dzielącego obie społeczności ${ }^{4}$.

Staram się sobie wyobrazić, co obserwował „zeuropeizowany" inteligent żydowski, taki jak Zamenhof, który o tym wszystkim wiedział i sam musiał stosować wobec Rosjan i Polaków uniki i nie rzucać się im w oczy. Albowiem zasadę maskilimów „bycia Żydem w domu, a człowiekiem na ulicy" można było stosować w ówczesnym Berlinie (tam też Mojżesz Mendelssohn rzucił to hasto), gdyż w Berlinie, Wiedniu czy Paryżu nikt na ulicy Żyda nie rozpoznał. Co innego w Polsce czy w Rosji.

3 W Polsce nakręcono około 30 filmów w języku jidysz, w tym klasykę kina Jidl mitn fidl Jana Nowiny-Przybylskiego i Josefa Greena z 1936 roku, Dybuk Krzysztofa Warlikowskiego z 1936 roku, Mamete Konrada Toma i Józef Greena z 1938 roku.

4 H. Datner, Ta i tamta strona. Żydowska inteligencja Warszawy drugiej połowy XIX wieku, Żydowski Instytut Historyczny, Warszawa 2007, s. 37. 


\section{KWESTIA ŻYDOWSKA}

Jak zauważa Daniel Grynberg, w XIX wieku w Europie powszechnie rozprawiano o trzech kwestiach $^{5}$ dotyczących rozdrobnionych, podzielonych czy zniewolonych narodów. Były to kwestie włoska, niemiecka i polska, i to one przyczynity się do upowszechnienia w epoce romantyzmu pojęcia "kwestia". Tak czy inaczej "kwestia” zawsze związana była czy to ze scaleniem narodowym, czy z niepodległością. Natomiast "kwestia żydowska” pojawiła się w zupełnie innym kontekście i stosunkowo późno, bo Żydzi żyjący we wszystkich państwach europejskich nie byli w tym okresie jakimkolwiek politycznym problemem, jak choćby Irlandczycy, żyjący na "skraju" zachodniej Europy. Poza tym liczba Żydów w Europie na początku XIX wieku nie przekraczała 2,5 mln osób, przy czym w państwach Europy Zachodniej nie stanowiła więcej niż procent ludności, jakkolwiek w Europie Środkowowschodniej można już było mówić o wyrazistych skupiskach ludności żydowskiej, głównie w licznych sztettech w Galicji.

Z czasem „kwestia" dotyczyła coraz większej liczby wątków, nie chodziło bowiem w niej ani o scalenie narodowe żyjących w diasporze Żydów, ani o wybicie się Żydów na niepodległość, niemożliwe bez posiadania terytorium, tym bardziej że Żydzi nie posiadali europejskiego „matecznika”. Nie znaczy to, że w niektórych politycznych programach żydowskich nie rodziło się marzenie, by w czasie zamętów politycznych, kryzysów, wojen, rewolucji, osłabienia walczących stron postulować jakiś ein osteuropäischer Staatenbund czy Judeopolonię. To oddzielny temat, najczęściej opisywany w kategoriach teorii spiskowych.

Większość Żydów, jeśli upatrywała w drugiej połowie XIX wieku jakiegoś „odrodzenia narodowego", to bardzo mgliście i raczej w związku z Erec Izrae/ ${ }^{6}$, co dobitnie wyrażą później w swych programach syjoniści. Również sami Żydzi stanowili konglomerat różnorodnych prądów społecznych, politycznych, religijnych i jakbyśmy dziś powiedzieli - reprezentowali najróżniejsze style życia. Na temat „kwestii żydowskiej” wypowiadali się wówczas niemal wszyscy intelektualiści, zarówno żydowscy jak i nieżydowscy.

\section{LUDWIK ZAMENHOF}

Tak naprawdę po raz pierwszy Zamenhof zobaczył Polskę dopiero w Warszawie w 1873 roku z kolejowego dworca Petersburskiego (dziś Wileńskiego) po przeprowadzce wraz z rodzicami z Białegostoku w 14. roku swego życia. Najpierw rzucić musiała mu się w oczy olbrzymia cerkiew św. Marii Magdaleny, która stoi tam do dziś. O tym, że Warszawa zarządzona jest przez Rosjan, Ludwik dowiedział się od ojca. To, że w Warszawie niemal na każdym kroku można spotkać Żydów, zobaczył na własne oczy na ulicach miasta, ale o tym, że jest to polskie miasto, przekonywał się każdego dnia coraz bardziej, obserwując życie społeczno-polityczne. Po raz pierwszy musiał sobie również zdać sprawę z tego, że znajduje się on między młotem a kowadłem, między narodowym żywiołem polskim i rosyjskim, będąc Żydem, który nie ma nic wspólnego z nieznaną mu Rosją, a jeszcze mniej z dopiero co poznawaną Polską.

5 D. Grinberg, Problem żydowski w Europie XIX wieku, "Studia Judaica”, nr 2(6) 2000, s. 169-177.

6 W 1841 roku Sir Montefiore za namową rabina Zvi Hirsh Kalischera (1795-1874) przeznaczył pieniądze na zakup pierwszego gaju pomarańczowego w Palestynie. W owym czasie w Palestynie żyło około 10 tys. Żydów, z czego około 500 w Jerozolimie. 
Biograf ma w związku z Zamenhofem problem polegający na tym, że Zamenhof niewątpliwie wykazuje wielką erudycję, zna podstawowe problemy epoki, posiada wiedzę historyczną, społeczną, rozprawy jego napisane są klarownie, natomiast raz może się zachwycać u Zamenhofa uniesieniami geniuszu ludzkiego, innym razem ma wrażenie, że czyta pisarzynę. Sam Zamenhof w wieku 58 lat, w ostatniej przed śmiercią rozprawie napisze: "Nie jestem filozofem-specjalistą, jestem tylko dyletantem"7. Nigdy i nigdzie nie pozostawiał jakiejkolwiek informacji o źródłach swojej wiedzy. Aleksander Korżenkow, niekwestionowany specjalista od "rosyjskiego" Zamenhofa, napisał mi:

W czasie moich poszukiwań w bibliotekach i archiwach Moskwy, Petersburga i Grodna przeczytałem wszystkie ówczesne roczniki czasopism „Русский еврей”, „Разсвет” і „Восход" (Недельная хроника). Ponieważ chodzi o prasę, którą niewątpliwie Zamenhof czytał podczas swoich studiów w Moskwie, przypuszczam, że w dużej mierze ta prasa go ukształtowała. Była ona płytka w debatach intelektualnych i jasno skierowana na szukanie wroga (, pogromszczyków", a głównie nieprawidłowo myślących Żydów, tak jak to znamy z ruchu esperanckiego, demaskującego fałszywych przyjaciół "naszej świętej sprawy"). Nie znalazłem w tych pismach z pierwszej połowy lat osiemdziesiątych XIX wieku żadnej interesującej rozprawy filozoficznej czy socjologicznej. Nie znam polskiego "Izraelity”, ale podług tych trzech rosyjskojęzycznych pism uważam, że były to w pełni asymilacyjne tytuły chcące stworzyć, jak w "Izraelicie", Polaków wyznania mojżeszowego, bardziej polskich niż sami Polacy8.

Można powiedzieć, że Zamenhof przyjął postawę proroka, który nie musi się tłumaczyć ze źródeł swej wiedzy: „Jesteśmy przekonani, że stoimy na fundamencie absolutnej prawdy [...]"9 - pisał w 1906 roku. Prorok po prostu wie, że głosi myśli jedyne, ostateczne i dodatkowo, jako posłaniec, niekoniecznie swoje. Ale również tu napotykamy problem, bo Zamenhof nigdy nie powoływał się w swoich ideach na jakieś objawienia. „Prawda absolutna" była mu dana, jako wynik racjonalnego myślenia, jako kwintesencja oświecenia. Myślę, że inspiracją dla wielu przemyśleń Zamenhofa był Moses Mendelssohn (17291786), z którego najprawdopodobniej zaczerpnął Zamenhof ideę, że judaizm nie jest objawioną religią, lecz objawionym prawem. Do rozważań społeczno-narodowych dochodził sam. Być może w jakimś stopniu inspirowali go Heinrich Graetz (1817-1891) czy Szymon Dubnow $^{10}$ (1860-1941), są to bowiem historycy, którzy nie przywiązują wagi do wypędzenia Żydów z Judei ${ }^{11}$, traktując ten epizod bardziej literacko niż historycznie, właśnie tak jak Zamenhof. Jeśli chodzi o zreformowanie judaizmu, to źródła myśli Zamenhofa w tej materii odnalazł Michel Clément:

Wpływy Haskali mają u Zamenhofa, jak się wydaje, źródła rodzinne i przyjmują u niego wymiar bardziej religijny niż laicki. Możemy niemal z pewnością odnaleźć część źródet jego analiz, pamiętając, że nigdzie nie są one explicite wskazane, w reformatorskim prądzie religijnym reprezentowanym przez rabinów Abrahama Geigera (1810-1874) i Samuela Holdheima (1806-1860). Geiger zwołał rabinów reformowanych podczas synodu i proklamował uniwersalną misję judaizmu. Nie ma tam już w modlitwach powrotu na Synaj ani rekonstrukcji Świątyni. Geiger uważał nawet obrzezanie za "ryt barbarzyński i krwawy". Wprowadza języki lokalne do kultu i uważa, że religia musi być wyzbyta jakichkolwiek nacjonalizmów. Holdheim, jeszcze bardziej radykalny, jest zdania, że należy oddzielić w łonie judaizmu elementy religijne i etyczne; kult ma być wyłącznie po niemiecku, a szabat ma być przeniesiony ze względów praktycznych na niedzielę. Jego zdaniem Talmud miał rację w swoich czasach, lecz on, Holdheim, wyraża swoje przekonania w swoich czasach, więc też ma rację. Te tendencje jeszcze bardziej rady-

$\bullet \cdot \bullet \bullet \cdot$

Mi estas Homo. Originalaj verkoj de d-ro L.-L. Zamenhof, red. A. Korjenkov, op. cit., s. 244.

Aleksander Korżenkow w korespondencji z autorem tej pracy w e-mailu z 4 XII 2008 (tłum. z esperanto).

9 L.L. Zamenhof, Originala verkaro (red. J. Dietterle), Ferdinand Hirt \& Sohn, Leipzig 1929, s. 326.

10 Zamenhof, pisząc swoją broszurę o hilelizmie, mógł znać jedynie pracę Dubnowa z 1893 roku, napisaną pod silnym wpływem Graetza Что такое еврейская история.

11 S. Sand, Comment le peuple juif fut inventé, Fayard, Paris 2008, s. 193-194. 
kalizują się wraz z dwoma liberalnymi rabinami, Davidem Einhornem (1809-1879) i Kaufmannem Kohlerem (1843-1926), którzy emigrują do Stanów Zjednoczonych, ponieważ odmówiono im możliwości służby rabinicznej w Bawarii, właśnie ze względu na liberalizm. Pragnęli oni, by bardziej respektowano prawo moralne nie-pisane niż nakazy Tory i Halachy; skądinąd nurt liberalny był związany z antysyjonizmem, szczególnie u Kohlera. Liberalny rabin Louis Germain Levy opublikował w 1904 roku esej Religia racionalna i laicka...? Jak można zauważyć, znaczną część tych idei znajdziemy u Zamenhofa [... $]^{12}$.

Język rozpraw Zamenhofa (a posługiwał się głównie rosyjskim i esperanto, rzadziej polskim, niemieckim i francuskim) nie jest językiem jakiejś dyscypliny naukowej, ale w jego epoce w naukach społecznych taki język dopiero się rodzit. Problemem jest kilka terminów, które Zamenhof używa stosunkowo często, jako oczywiste, jak na przykład zолyc ${ }^{13}$, народность сzу судьба, esperanckie gento, neŭtraleco czy sufereco i francuskie nation, peuple czy tribe, nawet do dziś niemożliwych do uzgodnienia równocześnie w porządku społecznym, politycznym i prawnym. Dodatkowo, niektóre pojęcia z czasów Zamenhofa zmieniły swoje znaczenie.

Czy można znaleźć w rozważaniach Zamenhofa coś oryginalnego? Z pewnością na uwage zasługują prekursorsko potraktowane zagadnienia, które niewątpliwie zostały zaczerpnięte z Zamenhofa, ale najczęściej „z drugiej ręki”, bez podawania źródeł ${ }^{14}$, a następnie się upowszechnity:

- wyodrębnienie etniczności jako zjawiska nieredukowalnych kulturowych sposobów bycia i życia grup narodowych czy etnicznych;

- obrona mniejszości narodowych czy etnicznych oraz wypracowywanie zasad moralnych i prawnych dla społeczeństw wielokulturowych;

- wkład do teorii polityki językowej;

- zagadnienia sprawiedliwości językowej;

- teorie interlingwistyczne.

Nie znalazłem w dziele Zamenhofa kłamstwa, podstępu, intryg. Ani jednego tekstu, w którym można by podejrzewać autora o narodową stronniczość czy nacjonalizm. Równocześnie pojawiają się teksty pełne stanowczego napiętnowania rasizmu, szowinizmu i ksenofobii. Poddawał się on demokratycznym decyzjom większości, zarówno w sprawach reform języka esperanto, jak i w sprawach ideowych. Różniło go to od większości twórców języków sztucznych, którzy często tyranizowali swoich adeptów i uważali się za nieomylnych. Zamenhof żył 58 lat. Swoje najważniejsze dzieło, czyli język esperanto, ukończył w 28. roku swego życia. Pozostałe 30 lat poświęcił na propagowanie esperanta i swych idei, których celem było „stopienie” Żydów z resztą ludzkości i stworzenie nowego narodu, a gdy uznał, że nie jest w stanie dokonać tego z Żydami, zwrócił się do społeczności międzynarodowej.

Zamenhof pozostał wierny umiarkowanemu judaistycznemu mesjanizmowi, ale potraktował swój naród wybrany jako jeden z narodów, który ma się rozpłynąć wśród wszystkich, w ten sposób zaznaczając w ludzkości swoją obecność. Albowiem: „Każdy naród wartościujemy nie liczbą dusz, nie siłą jego pięści, lecz tym, co wniósł on w ogólnoludzką

\section{-.....}

12 M. Clément, L'homanarisme, doctrine spirituelle, religion ou utopie humaniste?, http://www3.sympatico.ca/ mlgr/clement.pdf, 20 marca 2011.

13 Tytułem przykładu: ros. голус (synonim изгнание), w jidysz gałut, w hebr. תולג, które pojawia się w broszurze Гиллелизмъ czterdzieści razy, raz jako cierpienie, rozproszenie, innym razem wygnanie, tułaczka, odtrącenie, dokładniej „rozsianie” Żydów po całym świecie poza Izraelem. Jest w rosyjskim zapożyczone z jidysz, a w jidysz wzięło się z hebrajskiego, jednak do polszczyzny się nie dostało.

14 Znów podaje wyłącznie tytułem przykładu: Estończyk Valter Tauli (1907-1986), Amerykanin Joshua Aaron Fishman (1926 -) czy Francuz Louis-Jean Calvet (1942-) nie mogliby zostać luminarzami zagadnień polityki językowej i nie stworzyliby swych dzieł bez jakieś wiedzy o Zamenhofie, a bez wątpienia o esperancie. 
skarbnicę"15. Nic dziwnego, że Zamenhof nie mógł zyskać żadnego poparcia narodowego. Stał się wrogiem nacjonalistów najróżniejszej maści, zjednoczonych w tym, by nie godzić, a jątrzyć i dzielić. Nic dziwnego też, że w takiej sytuacji esperanto nie uzyskało żadnego wsparcia państwowego, a stało się obiektem szyderstw nacjonalistycznych pismaków i wyniszczających ataków tajnych służb.

HILELIZM

Zamenhof publikuje swoją broszurę Гиллелизмъ. Проектъ ръшенія еврейскаго вопроса w 1901 roku, mając 42 lata, gdy znany jest niemal na całym świecie jako autor esperanta. Język ten ma wówczas za sobą 14 lat rozwoju i rozpowszechniania. Broszurę podpisuje pseudonimem Гомо Сум, a kieruje ją do rosyjskojęzycznej inteligencji żydowskiej. Jest w niej analiza kondycji Żydów, przyczyn antysemityzmu, krytyka syjonizmu, są drogi wyjścia, a nade wszystko sposoby, w jakie hilelizm należy wprowadzić w życie, wraz z organizowaniem nowej obrzędowości, przeznaczeniem świątyń itp. Poniżej zajmę się wyłącznie najważniejszymi zagadnieniami.

W przeciwieństwie do Żydów szukających przyczyn antysemityzmu wokół siebie, Zamenhof upatruje go w samym żydostwie. W pierwszej kolejności określa stan świadomości egzystencji Żydów jako голyc: wygnanie, rozproszenie, cierpienie - kluczowe pojęcia u Zamenhofa. Pod tym wszystkim kryją się pogromy, prześladowania, szykany, poniżenie, szydzenie, kpina, odpychanie Żydów od otaczających go społeczności, oskarżanie Żydów o chęć podszycia się pod inne narody, „zażydzanie” literatury obcej6 i obcych języków.

W katalogu win Żydów nie ma u Zamenhofa, co zrozumiałe, argumentów antysemickich, a więc oskarżeń o lichwiarstwo, skąpstwo, przebiegłość, profanacje hostii, zabójstwa rytualne, czy chęć panowania nad światem, które najczęściej wywodziły się z inteligenckich środowisk antysemickich, ale i kościelnego i cerkiewnego pospólstwa.

Wypędzenie Żydów nie jest boską karą za grzechy, jest to konsekwencja sprzeniewierzenia się misji narodu żydowskiego, niewłaściwie odczytanego przez talmudystów, tak jak utożsamienie Boga z narodem wybranym, a narodu z ziemią obiecaną. Dalej, wypędzenie i cierpienia Żydów spowodowane są brakiem posiadania państwa żydowskiego i wspólnego Żydom języka. Podsumujmy: Żydzi są rozproszeni, z tego powodu cierpią, ponieważ zagubili sens swej misji dziejowej, zatracili naród, utracili jezyk, wszystko to niejako z własnej winy, tkwiącej w rabinicznym judaizmie. Tu tkwi istota problemu, który hilelizm ma uleczyć.

By ponownie zaistniał naród żydowski, który zrzuci z Żydów cierpienie, należy przywrócić im właściwą misję dziejową, właściwe pojmowanie Boga jako przynależnego wszystkim. Znalezienie i wyznaczenie dla ludu nowego terytorium, i rozpoczęcie posługiwania się jednym, wspólnym dla Żydów językiem. „Hilelizm zdejmie z Żydów kajdany, a to, co dla talmudystów jest zawsze niemożliwe, dla hilelistów będzie możliwe"17.

15 Гиллелизмъ. Проектъ ръшенія еврейскаго вопроса. Reprint oryginału wraz z tłumaczeniem na esperanto przez A. Holzhausa, Fondumo Esperanto, Helsinki 1972, s. 56.

16 Po raz pierwszy "zażydzanie" literatury obcej pojawi się w antysemickich oskarżeniach niemieckich przeciwko twórczości Heinricha Heinego (1797-1856). W Polsce znacznie później, w związku z takimi twórcami jak, na przykład, Julian Tuwim (1894-1953).

17 гиллелизмъ, оp. cit., s. 66. 
Zasady moralne. W naukach etycznych przyjęło się określać pewne uniwersalne aforyzmy nauczycieli ludzkości jako "złotą regułę”. Ze starożytności najczęściej cytujemy te oto:

- w dobroci i cierpieniach musimy powstrzymać się od krzywd wyrządzanych innym, których sami nie chcielibyśmy doświadczać (Yogashastra 2, 20);

- nie czyń drugiemu tego, co tobie wyrządziłoby utrapienia (Mahabharata, 5, 15, 1);

- nie rań bliźnich tym, co rani ciebie (Buddha: Sutta Pitaka, Udanavagga 5, 18);

- to, czego nie chcesz, by czyniono tobie, nie czyń innym (Konfucjusz: Analecta 15, 23);

- nie czyń drugiemu, co tobie niemiłe. To całe Prawo, reszta to komentarz (Hillel: Talmud bab, Shabbat 31a).

„Wybór nazwy hilelizm bierze się z tego, że sam Zamenhof uważał własne interpretacje religijne za zgodne z zasadami głoszonymi przez Hilela"18. Sofistyczne i kazuistyczne, a równocześnie klarowne interpretacje Pisma przez Hilela niewątpliwie musiały skłonić Zamenhofa do tego, by nie mieć oporów w reformie judaizmu, nie w dogmatyce, ale w przeinterpretowaniu zasad i form. Przecież to uczynili Chasydzi. Pozostali wierni judaizmowi niemal co do litery, a zmienili całkowicie formę judaizmu! Dlaczego nie zamienić formy judaizmu na całkowicie świecką? W ten sposób „zagadnienie wywołane W Talmudzie (Szabbat, 31): "Nie czyń bliźniemu, co tobie niemiłe» uzyskuje następujące rozwiązanie: nie Bóg jest centrum wszechświata, lecz człowiek ze swą miłością"19.

Judaizm należy tak zreformować, by $w$ dalszym ciągu pozostał judaizmem z ducha, ale nie z litery. Hillel (przełom I w. p.n.e. i I w. n.e.), przez wielu uważany za nauczyciela Jezusa, nie służy Zamenhofowi wyłącznie jako autor jednej z najwspanialszych myśli człowieka, przywoływanej najczęściej od Chrystusa po Immanuela Kanta, to byłoby zbyt bezceremonialne, ale głównie jako komentator Ksiąg podług ducha i niedościgniony interpretator Prawa. Tą drogą na swój sposób podąża w hilelizmie Zamenhof.

To taka sama religia mojżeszowa jak talmudystów czy karaimów, lecz interpretowana nie literalnie, a symbolicznie. A że duch mojżeszowy jest czymś nieuchwytnym, rozsianym po całej Biblii, może on dawać pretekst do najróżniejszych jej interpretacji. Stąd hileliści zmuszeni są jasno sformułować istotę tego ducha w kilku precyzyjnych pryncypiach, a te są następujące:

1. Odczuwamy i uznajemy istnienie najwyższej Siły, która rządzi światem, i Siłę tę nazywamy Bogiem.

2. Bóg włożył swoje prawa w serce każdego człowieka w formie świadomości, dlatego bądźmy zawsze posłuszni głosowi rozsądku, gdyż jest to niezamilkły głos Boga.

3. Istota wszystkich praw boskich jest wyrażona w następującej zasadzie: kochaj bliźniego i postępuj wobec niego tak, jakbyś chciał, by on postępował w stosunku do ciebie. Niczego nie rób jawnie ani skrycie, o czym twój wewnętrzny głos mówitby, że to się nie spodoba Bogu.

Wszystko inne, co usłyszysz od swoich nauczycieli czy przodowników, a co nie zawiera się w pierwszych trzech punktach, to wyłącznie ludzkie komentarze, które mogą być prawdziwe, ale mogą też być błędne ${ }^{20}$.

Naród. Żydzi nie są narodem, a tylko grupą etniczną. Posiadają pewne cechy narodu wynikłe z judaizmu, w stopniu, w jakim posiadają je inne narody, na przykład Polacy czerpiący z katolicyzmu. Ale nie posiadają najważniejszego atrybutu narodu, języka. To, że ktoś wyznaje katolicyzm, nie znaczy automatycznie, że jest Polakiem, natomiast wyznawca judaizmu jest automatycznie Żydem. Ale czy Żydem, który przynależy religijnie do judaizmu, czy Żydem, który przynależy do narodu... Jakiego? To jest paradoks. Żydzi mogliby stać się narodem, są nawet krok od tego, ale:

18 A. Cherpillod Les trois rêves humanistes du docteur Zamenhof, Édition de la Blanchetière 2007, s. 41.

19 G. Silfer, Se mi ne estas Hebreo... Una ricerca sulle origini dell'esperanto, Centro Italiano di Interlinguistica, Milano 1986, s. 13.

20 гиллелизмъ, ор. cit., s. 41-43. 
Co prawda, my Żydzi wschodnioeuropejscy, mamy wspólny język, którego używali nasi rodzice i dziadowie, którym posługiwaliśmy się w dzieciństwie i którym jeszcze dziś często się posługujemy, to żargon. Gdybyśmy jednak ten język doskonalili literacko i nakazywali posługiwać się nim naszym dzieciom i wnukom, wtedy mielibyśmy prawo nazwać się narodem. Bylibyśmy prawdziwym narodem, a nie fikcją. Bylibyśmy narodem mieszkającym w zachodniej Rosji i w Polsce, posługującym się żargonem i nie mielibyśmy oprócz religii nic wspólnego z innymi Żydami i z Palestyną. Taka konstrukcja narodowa, choć niepostulowana, byłaby przynajmniej naturalna. Ale taki naród, doskonalący jidysz w zonie rosyjsko-polskiej między Bałtykiem a Morzem Czarnym nigdy nie zostałby uznany przez żadne hebrajskie stronnictwo, mało tego, jego szanse istnienia byłyby efemeryczne, bez żadnych widoków na przyszłość21.

Język. Starohebrajski jest językiem ksiąg, nie sposób by posługiwał się nim lud, zresztą w formie obecnej (przed wylansowaniem nowohebrajskiego przez Eliezera Ben-Jehudę, 1858-1922) nie da się nim posługiwać współcześnie, a przecież lud potrzebuje najbardziej języka. Odrodzenie hebrajskiego nie ma sensu, podobnie jak doskonalenie żargonów.

Proszę nie myśleć, że jestem nieprzyjacielem żargonu. Przeciwnie, choć niemal bez wyjątku cała nasza inteligencja (nie wyłączając pisarzy tego języka) ma do żargonu negatywny stosunek i uważa go za coś prostackiego, zawsze podchodzitem do żargonu z sympatią, a nawet jak dziś - z umitowaniem, widząc w nim taki sam język jak inne. Przed 20-25 laty przez długi okres, z zapałem i pasją pracowałem nad tym językiem i przekonałem się, że posiada on nie tylko niezliczone bogactwo form, ale logiczną i uporządkowaną gramatyke, w wielu miejscach oryginalną i godną studiów. Tę gramatykę systematycznie opracowywałem i byłem gotów opublikować ją, równocześnie marząc o czystej i uduchowionej nowohebrajskiej literaturze, zamiast opacznej i kalekiej. Lecz wkrótce doszedłem do wniosku, że byłoby to bezcelowe i bez przyszłości, a prezentując żargon chędogi, w istocie tymczasowy dialekt, nie będzie jego najmniejszego związku z hebrajskością, a przez jego doskonalenie nic nie wniosę w hebrajskość22.

Jeśli nie hebrajski, jeśli nie żargon, a właściwie liczne żargony (nie tylko dialektalnie zróżnicowane, ale genetycznie różne, jak jidysz, krymczacki, aravic, szuadit czy ladino), pozostaje trzeci wariant, już praktycznie sprawdzony, esperanto.

Można powiedzieć à priori, że sztuczny język, do którego mamy prawo w nieograniczonych wymiarach wnieść, co nam się podoba, najlepiej spełni wszystkie niezbędne warunki języka: możemy go bez ograniczeń wzbogacać, jest on giętki, pełny igraszek, które nadają językowi żywotność, ma piękne brzmienie oraz nadzwyczaj łatwo się go nauczyć. I rzeczywiście, prace ostatnich dziesięcioleci wykazały, że taki język nie tylko może istnieć, ale może zadawalać najbardziej wyrafinowane potrzeby, i że jest on na tyle łatwy - a to jest najważniejsze - że nawet nieoświecony człowiek może go sobie z łatwością przyswoić w ciągu tygodnia (dzieci zaś, w naturalny sposób, mogą go sobie przyswoić od urodzenia) ${ }^{23}$.

Terytorialiści i syjoniści. Żaden współczesny naród nie mieszka tam, gdzie była jego kolebka. Wszyscy Europejczycy przywędrowali z Azji. Kurczowe trzymanie się Palestyny jako ziemi praojców jest nieuzasadnione, gdyż nie da się udowodnić, że my Żydzi jesteśmy genetyczną kontynuacją Hebrajczyków sprzed 20 wieków z tamtej ziemi. To mit.

Żydzi już dawno znaleźliby taki punkt oparcia, gdyby w inny sposób interpretowali religię. Garstka Fenicjan, którzy stracili ojczyznę, założyła potężną Kartaginę, zdruzgotana pięść Trojan założyła wielki Rzym, garstka wypędzonych Holendrów zbudowała południowe republiki afrykańskie, garstki różnych prześladowanych protestantów założyły potężne Stany Zjednoczone. Wszędzie po zdruzgotanym życiu zaczyna się nowe życie... i tylko my, jedynie my, od 2000 lat nie możemy znaleźć sobie przystani, bo gdziekolwiek byśmy dotarli, cień Palestyny, oparty na naszej religii, zmusza nas do pozostawania wszędzie obcymi, do prowizorki, a religijno-gene-

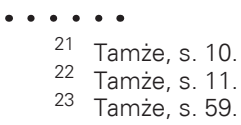


alogiczna otoczka nie pozwala nam wypłynąć na świat zewnętrzny. Dodatkowo, niezliczone obowiązki i zakazy, których nikt nie ma prawa podważyć, są dowodem na to, że samodzielny nasz byt jest niemożliwy. Hilelizm zdejmie z Żydów kajdany... ${ }^{24}$.

Możemy kupić ziemię choćby w Ameryce ${ }^{25}$ i założyć tam własne małe państwo, możemy nawet kupić piędź ziemi w Palestynie, tyle że tam państwa nie da się zbudować, ale można będzie jakoś żyć. Reszta Żydów na świecie będzie miała miejsce, do którego, jeśli zechce, zawsze będzie mogła się udać. Zamenhof nie wykluczał możliwości osiedlenia się Żydów w Palestynie:

Jako kolebka naszej historycznej grupy etnicznej, naszego „narodu”, Palestyna będzie tak samo droga dla hilelistów, jak i dla innych Żydów, gdyż po kilku latach, gdy hileliści wzmocnią się, będą chcieli prawdopodobnie zakupić na własność piędź tamtejszej ziemi, z którą związana jest pamięć o młodości naszego ludu. Lecz u hilelistów ta miłość do Palestyny jest tylko czcią, ale nie rozwiązaniem kwestii żydowskiejej.

W latach studenckich Zamenhof był aktywnym syjonistą, ale zrezygnował z tej idei, nie widząc możliwości odrodzenia państwa Izrael na terenie imperium otomańskiego. „Przyglądał się syjonizmowi z największym sceptycyzmem, jako konstrukcji sztucznej i narodowo fałszywej"27. Nie wierzył w możliwości politycznego zorganizowania się tam Żydów, a przerażony konduitą pierwszych pionierów z Bilu (których uważa się za pierwszą aliję do Izraela), roztrwonieniem przez nich przekazanych im środków, zarzucił całkowicie tę ideę. Uzasadniając w wielostronicowych rozważaniach swą postawę, konkluduje:

Dlatego działalność syjonistów sama przez się musi być nazwana b e z u ż y t e c z n ą. Lecz na szczęście sprawy biegną inaczej i działalność syjonistów przyniesie nieoczekiwaną korzyść: oto bowiem te całe konfabulacje syjonizmu pękną jak bańka mydlana, zaś wywołane przez syjonizm przebudzenie narodu (a dokładniej grupy etnicznej), samoświadomość i cel zbawienia, przyniesie pozytywne owoce. Sam syjonizm, gdy znajdzie się w rękach intelektualistów, wcześniej czy później zostanie przez nich unieważniony, by uratować hebrajskośćz 28 .

Misja. Żydzi mają do spełnienia misję dziejową polegającą na tym, że mają utworzyć jedną wielką ludzką rodzinę:

Hilelizm raz zakorzeniony, nigdy nie osłabnie, nie zachwieje się, nie przestraszy się światłości, nie przeciwstawi się nauce, nigdy nie wystawi ludzi na cierpienia wewnętrznej walki na drodze postępu cywilizacyjnego, do czego zmusił ludzi judaizm talmudyczny. Hilelizm będzie trwać tak długo jak ludzkość i będzie dla przyszłych pokoleń żydowskich niewysychającą krynicą ludzkiego ciepła. Ta religia będzie przydatna zarówno dzikiemu Afrykańczykowi, jak i najbardziej wykształconemu Europejczykowi, zarówno najbardziej nieoświeconemu tubylcy żyjącemu jak w prehistorycznych czasach, jak i oświeconym reprezentantom przyszłości. Bo Hilelizm nie zależy od żadnych narodowych właściwości ani od miejsca, ani od czasu, ani od stopnia ewolucji i nieuzależniony jest od narzuconych sobie kajdan, ale bazuje na sercu i rozumie, zawsze się do nich przysposabiając ${ }^{29}$.

\section{-....}

24 Tamże, s. 66.

25 Gdy Zamenhof pisał rozprawę o hilelizmie, Arizona, Oklahoma i Alaska nie wchodzity jeszcze w skład Stanów Zjednoczonych. Zamenhof w pracy z 1882 roku 4 то же наконец делать? pisat: „Wybierzcie jakiś skrawek Stanów Zjednoczonych, możliwie najrzadziej zaludniony, i tam skierujcie migrację. Nazwijcie go miejscem zjednoczenia i tam powędrują Żydzi, ze wszystkich zakątków ziemi. Początkowo będą oni pod bezpośrednim zarządem Federacji, ale tworząc swoje terytorium i osiągnąwszy liczbę 60 000, będą mieć prawo na mocy konstytucji prosić o proklamowanie ich terytorium stanem w ramach północnoamerykańskiej konfederacji. W ten sposób przejście od zarządu federalnego po samostanowienie stanie się łatwe i niezauważalne".

26 Гллелизмъ, op. cit., s. 77.

27 A. Künzli, Esperanto, Hillelismus (Homaranismus) und die "jüdische Frage" in Ost- und Westeuropa, Verlag Harrassowitz, Wiesbaden 2010, s. 168.

28 Гллелизмъ, op. cit., s. 78.

29 Tamże, s. 49. 
Wypędzenie, cierpienie, wspólne pochodzenie. Jest to niczym nieuzasadniona martyrologia, którą Żydzi przypisali niewiadomo komu, podczas gdy w czasie rewolty Żydów w latach 66-70, a następnie w latach 132-135, co prawda, Rzymianie okrutnie ich zabijali i masakrowali, ale nikt nie wygnał zwykłych pasterzy i rolników z Palestyny, by można było mówić o masowej deportacji czy o pełnym rozproszeniu. Nieustające odwoływanie się do tych wydarzeń jest bezpodstawnym usprawiedliwianiem swojej doli. Hileliści odrzucają ten mit.

Nowy naród. Przed Zamenhofem jedynie wielcy prorocy religii i utopiści marzyli o nowym człowieku. Wszystko w ramach duchowego przeobrażenia jednostek. Jako pierwsi eksperci z zakresu inżynierii ludzkiej przekuwali te przeobrażenia w czyn francuscy rewolucjoniści. Po nich eksperymentowano z człowiekiem radzieckim, jugosłowiańskim, nie wspominając o nazistowskich zbrodniarzach, maoistach i im podobnych. Jeszcze w 1901 roku Zamenhof pod wpływem sukcesów esperanta wierzył, że przekona Żydów do niego i że esperanto połączy Żydów niemających jednego wspólnego języka, a oni, dając przykład innym, przekonają całą ludzkość. Powszechny neutralny język niebędący „własnością" żadnego narodu, a należący do wszystkich, połączy ludzkość. Zamenhof był jednak mistrzem kamuflażu, nigdzie więc nie napisał tego $w$ tak radykalnej postaci, jak ja uczynitem to wyżej. Ale w istocie o to mu chodziło.

Niezłomnym moim celem będzie zawsze stopić Żydów z całą ludzkością, gdyż jestem przekonany, że dla rozsianych po całym świecie Żydów jest to najlepsze i jedyne wyjście, z czego wyniknie coś wielkiego i zbawiennego dla całej ludzkości, w tym jest bowiem wyrażona misja narodu żydowskiego, który niedaremnie i nie bez celu historia porozrzucała po wszystkich zakątkach ziemi30.

Nie znamy listu, który przesłał Zamenhofowi z Odessy Abram Kofman (1864-1940), zdegustowany broszurą Hilelizm. Kofman nawet nie doczytał jej do końca. Domyślamy się z listu Zamenhofa z 15 maja 1901 roku, że Kofman musiał w nim napisać, iż sam hilelizm zaszkodzi esperantu, więc dobrze by było, gdyby Zamenhof skupił się na esperancie i nie szkodzit jego reputacji. Zamenhof odpisał w nieoczekiwany dla historyków esperanta sposób. Oto jawi się on nie jako optymista i utopista, ale wyrachowany strateg:

To prawda, że esperanto ma w tej chwili najbardziej obiecujące szanse na przyszłość, a jednak dostatecznie nauczony doświadczeniami, nie byłbym aż takim optymistą! Był okres, kiedy Volapük stał przed świetlanym sukcesem, a jednak szybko jak błyskawica Volapük zniknął i ze wszystkich jego obiecujących nadziei nic nie pozostało. I nawet gdyby wszystkie akademie świata przyjęły esperanto, choćby nawet było ono w użyciu miliona ludzi, nic nie gwarantuje, że kiedyś nagle może być ono odrzucone i zapomniane na zawsze. Jeśli raz tylko byłoby ono usunięte "ze świata”, nigdy nie miałoby do niego powrotu. Język międzynarodowy może zaistnieć na zawsze tylko wtedy, gdy znajdzie się grupa ludzi, która przyjmie go jako język ojczysty, przekazywany z pokolenia na pokolenie. Setka takich ludzi jest dla idei neutralnego języka więcej warta niż miliony innych. Język przekazywany w schedzie, nawet przez naród najmniejszy i bez znaczenia, daje mu pewniejszy żywot i niezniszczalność, niż czyni to język bez narodu, którym posługują się miliony ludzi.

Tak, jestem dogłębnie przekonany, że ani rozwiązanie kwestii żydowskiej, ani zaistnienie neutralnego języka nie jest możliwe bez hilelizmu, to znaczy bez n e u tra In e g o na ro d u¹.

Zamenhof zbierał cięgi za głoszone idee, esperanto bowiem odnosiło sukcesy i większość esperantystów, szczególnie francuskich i polskich, obawiała się, podobnie jak Kofman, że „upiększanie” esperanta ideologiami sprowadzi samo esperanto na manowce.

30 Tamże, s. 62.

31 Mi estas Homo. Originalaj verkoj de d-ro L.-L. Zamenhof, op. cit., s. 97. 
Zamenhof, rozczarowany w stosunku do żydowskiej inteligencji, powie w wywiadzie dla londyńskiej "Jewish Chronicle” z 6 września 1907 roku: „Czy udało się Panu przekonać wielu ludzi? - Nie. Rosyjscy Żydzi nie chcą się wypowiedzieć w tej sprawie".

Zamenhof trwał w uporze i kilka lat po hilelizmie opublikował rozprawę o homaranizmie, w oryginale po esperancku (nie jak Hilelizm po rosyjsku), tym razem zwracając się już nie wyłącznie do Żydów, ale do wszystkich ludzi dobrej woli. Można powiedzieć toutes proportions gardées, że Zamenhof z „Szawła” staje się „Pawłem”, ale to już inna historia.

\section{JAK ZOSTAL WYMYŚLONY NARÓD ŻYDOWSKI?}

Właśnie jestem po lekturze ponadczterystustronicowej pracy Szlomona Sanda zatytułowanej Comment le peuple juif fut inventé. Książka napisana po hebrajsku była przed kilkoma laty przez 14 tygodni największym bestsellerem czytelniczym w Izraelu. Głównym tematem książki jest wykazanie, że do XIX wieku Żydzi nie uważali się za naród, a tylko za wspólnoty wyznaniowe. Według autora myśl, że etnos żydowski może istnieć niezależnie od judaizmu, jest wymysłem XIX-wiecznym, obcym judaizmowi inicjującemu. Syjoniści uprawiali "politykę historyczną”, która stała się mitem założycielskim państwa Izrael, według którego Żydzi wrócili z wygnania, z diaspory, do Ziemi Obiecanej. Samo pojęcie diaspory jest problematyczne, gdyż nie da się udowodnić, biorąc pod uwagę konwersje pogan na judaizm z okresu od początków chrześcijaństwa po narodziny islamu, jaki element etniczny stanowili Hebrajczycy, jeśli uwzględnić najróżniejsze teorie dotyczące Chazarów, Karaimów, i zważywszy na to, że jeszcze w XII wieku niektóre plemiona berberyjskie wyznawały judaizm, nie mówiąc o współczesnych Felaszach, ludzie kuszyckim z Etiopii.

Szlomo Sand, podobnie jak Zamenhof, kwestionuje jako wydarzenie historyczne wypędzenie Żydów z Judei po buntach i rewoltach z lat 66-70, a następnie 132-135. Dopiero od IV wieku można zaobserwować wyraźny spadek liczby adeptów judaizmu w Palestynie. Najprawdopodobniej w tym okresie następują masowe konwersje Żydów na chrześcijaństwo i wiąże się to z upadkiem imperium rzymskiego. Niewykluczone, że niektórzy obecni Palestyńczycy, jak już w 1929 roku uważali David Ben Gourion i Yitzhak Ben-Zvi, to pierwsi Żydzi tego regionu².

\section{GDYBY NIE ENDLÖSUNG DER JUDENFRAGE?}

Jak wyglądałby świat po II wojnie światowej, gdyby nie było Zagłady? Trudno jest „wróżyć", ale:

- W Europie ukształtowałby się nowy naród żydowski, nie religijny, a świecki, języka i kultury jidysz, a spora część Żydów emigrowałaby do Ameryki.

- Izrael nie zostałby niepodległym państwem. Jeśli takim został w 1948 roku, to jako „rekompensata” za Holokaust. Część Żydów z Brytyjskiego Mandatu Palestyny musiałaby wracać do Europy lub wyjeżdżać do Ameryki.

- Pozostali na terytorium Palestyny wegetowaliby jako kilkadziesiąt umiarkowanych formacji syjonistów, a może kilkaset kibuców czy innych form religijno-wspólnotowych

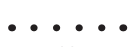

32 S. Sand, Comment..., op. cit., s. 262-266. 
à la Hasydzi (jak amerykańscy Huterytyci czy Amisze), doskonaląc język nowohebrajski, ciesząc się jakąś wewnętrzną autonomią w ramach, powiedzmy Królestwa Jordanii, w pełni kontrolowaną przez tajne policje arabskie, i płacąc wysokie sumy za dzierżawę ziemi.

- Państwa arabskie żyłyby w sojuszu z Ameryką, gdzie mieszkaliby prawdziwi Żydzi mówiący na co dzień po angielsku, a w Polsce mieszkaliby nieprawdziwi Żydzi mówiący w jidysz. W Europie królowałaby niemczyzna.

- W Polsce trwałaby dyskusja co do przyznania terytorialnej autonomii Żydom, autonomię kulturową posiadałyby bowiem już niemal wszystkie narody i grupy etniczne Europy. Zresztą taką autonomię kulturową otrzymali Żydzi po 1944 roku w ramach Centralnego Komitetu Żydów w Polsce, mając w pełni możliwość urządzenia życia po swojemu³.

- Wciąż dyskutowano by o kwestii żydowskiej, która sprowadzałaby się do jednego zagadnienia: jakie terytorium i czy w ogóle „wyznaczyć” w Europie Żydom.

Scenariusze takie można mnożyć, lecz ich wspólny mianownik byłby następujący: Żydzi języka i kultury jidysz są narodem, a równocześnie są realnym problemem Polski i Europy, a że zamieszkują głównie Polskę, to właśnie Polska ma rozwiązać „kwestię żydowską"34. "Kwestia żydowska" nie dawałaby spokoju najróżniejszym formacjom faszystowskim, antysemickim, skrajnym odłamom ultrachrześcijańskim, podsycano by propagandę o spisku żydostwa i masonerii przeciwko Europie, wierze, narodom...

WNIOSKI

Przeczucie kryzysu krążyło od początku XX wieku po Europie. Zamenhof jako jeden z nielicznych, a może jedyny z Żydów przedstawił projekt, nazwany hilelizmem, w którym postulowat, by rozwiązać kwestię żydowską, rozpoczynając od „zreformowania” samych Żydów, tak by można było zachować hebrajskość i czuć dumę z bycia Żydem, na każdym miejscu na ziemi, gdzie rodzili się i mieszkali Żydzi, bez wchodzenia w konflikt z otoczeniem. Były to jednak dla Żydów reformy zbyt radykalne, nie ze względu na ich treść, ale raczej formę, ze względu na zakorzenione tradycje i reakcję rabinów, za którymi podążało pospólstwo. W każdym punkcie hilelizmu jest konflikt z tradycją, począwszy na przykład do tego, że esperanto było zapisywane w "gałches", czyli w zabronionym Żydom alfabecie łacińskim, po zakwestionowanie wypędzenia jako faktu historycznego dotyczącego diaspory żydowskiej. Zamenhof wiedział, że nie trafi do mas, dlatego zwrócił się do inteligencji żydowskiej w Rosji, gdzie kwestia żydowska była najbardziej napięta. Inteligencja żydowska nie potrafiła jednak wypracować żadnego programu narodowego, bo już na początku XX wieku dzieliła się na asymilatorów, terytorialistów, syjonistów, autonomistów, fołkistów itp., widzących naród żydowski inaczej, a nade wszystko w innym miejscu na ziemi.

Patrząc dziś z ponadwiekowej perspektywy na hilelizm i na wszystko to, co się później stało, dochodzę do wniosku, że „natarcie” przeciwko Żydom było w chrześcijańskiej Europie pierwszej połowy XX wieku nieuniknione. Sam jestem przerażony tą konstatacją.

33 Między innymi wspólna żydowska reprezentacja polityczna, pluralizm polityczny i organizacyjny, odrębne szkolnictwo, prasa, własna spółdzielczość, jednostki samoobrony, wolność emigracji oraz możliwości korzystania z pomocy zagranicznej. Inne powody zadecydowały o „wymarciu” tej autonomii, przed 1950 rokiem, nikt jej bowiem formalnie nie unieważnit.

34 Jeszcze niedawno, przed przystąpieniem Słowacji, Czech i Rumunii do Unii Europejskiej, państwa te miały rozwiązać "kwestię cygańską", choć rozprawiano o tym wyjątkowo delikatnie i używano nad wyraz poprawnych politycznie pojęć. 
Zauważam coraz częściej, że nie jestem odosobniony. Na przykład Piotr Paziński, redaktor "Midrasza", pyta:

Jak byłoby, gdyby nie Hitler? Tego nigdy się nie dowiemy. Ale wszystko przemawia za tym, że II Rzeczypospolitej nie dałoby się przerobić w liberalną demokrację w stylu amerykańskim i Żydzi i tak musieliby z niej masowo zwiewać. Może zostałaby jedna trzecia, wytworzyłaby się jakaś nowa jakość, jak w Hiszpanii i Portugalii w XIII wieku. Ale i tamten eksperyment skończył się dwa wieki później na placu Rossio, bo dwójce hiszpańskich fanatyków ${ }^{35}$ zamarzyło się państwo judenfreß ${ }^{36}$.

\section{LUDWIK ZAMENHOF'S ATTEMPT AT SOLVING THE JEWISH QUESTION}

\section{Summary}

Zamenhof is well-known as the creator of the international language Esperanto. The origins of Esperanto stem from Zamenhof's attempts to convince Jews that they could form a nation, even without territory, on the basis of a language, namely Esperanto; otherwise, they would always be an ethnic group only. Zamenhof presented his doctrine in 1901 in a Russian language leaflet entitled Hilelism. He decided to address the Jewish intelligentsia in Russia, where the Jewish issue was most pronounced and tense. But the Russian intelligentsia was unable to work out a national program. Already at the beginning of the 20th century, it was split into many groups with a variety of standpoints, and each group perceived the Jewish nation in a different way and, most importantly, located its seat in a different part of the globe. Esperanto itself, however, became increasingly more popular at that time. Its adherents strongly criticised a broad spectrum of different, mildly utopian doctrines on how to solve the Jewish issue. Zamenhof reedited his Hilelism in such a way that his efforts to solve the Jewish issue began to be absorbed into broad humanism. Later, he gradually promoted Homaranism, being at a distance from Judaism itself. Zamenhof finally believed that he left Esperanto, not to a "specific ethnic group," but to all humanity.

Keywords: Ludwik Zamenhof, Esperanto, the Jewish issue, Homaranism

\footnotetext{
35 Tymi fanatykami byli monarchowie katoliccy Ferdynand Aragoński (1452-1516) i Izabela Kastylijska (14511504), którzy zakończyli dzieło rekonkwisty i zmusili portugalskiego króla Manuela I Szczęśliwego (1469-1521), w zamian za poślubienie ich córki Izabeli z Asturii, uczynić Portugalię (tak jak wcześniej zrobili to z Hiszpanią) królestwem "Judenfrei" czyli wolnym od Żydów. W polityce Manuela przeważył, w okresie rosnącej potęg imperialnej Portugalii, jakbyśmy to dziś powiedzieli, interes narodowy, wymagający poświęcenia Żydów. I mimo wszystko uczynit to Manuel Szczęśliwy, wielki przyjaciel Żydów.

36 Europa to paskudne miejsce. Z Piotrem Pazińskim rozmawia Karolina Felberg, „Odra”, nr 9/2010, s. 84
} 